\title{
Potential Effects on Human Health of Hydrogen Sulfide Exposure in a Place in Southeast of Mexico
}

\author{
Manuel Muriel-García1, Rosa María Cerón-Bretón'², Julia Griselda Cerón-Bretón ${ }^{2}$ \\ ${ }^{1}$ Instituto Mexicano del Petróleo, Ciudad del Carmen, México \\ ${ }^{2}$ Facultad de Quimica, Universidad Autónoma del Carmen, Ciudad del Carmen, México \\ Email: jceronbreton@pampano.unacar.mx
}

Received 10 November 2015; accepted 15 January 2016; published 18 January 2016

Copyright $@ 2016$ by authors and Scientific Research Publishing Inc.

This work is licensed under the Creative Commons Attribution International License (CC BY). http://creativecommons.org/licenses/by/4.0/

(c) (i) Open Access

\begin{abstract}
Ambient concentrations of $\mathrm{H}_{2} \mathrm{~S}$ were determined by modeling the $\mathrm{H}_{2} \mathrm{~S}$ emissions dispersion for three sites located in the surroundings of oil and gas maritime terminal at the southeast of Mexico. Hazard quotient is reported for different age groups. Paraiso City in Tabasco State reported the highest values for over 19 years old group $(0.49)$. It was concluded that there was no threat to human health due to $\mathrm{H}_{2} \mathrm{~S}$ emissions derived from the maritime terminal for the studied sites.
\end{abstract}

Keywords

Risk assessment, $\mathrm{H}_{2} \mathrm{~S}$, Air Pollution, Southeast of Mexico

\section{Introduction}

Some communities have expressed health concerns over low-level exposure to hydrogen sulfide $\left.\left(\mathrm{H}_{2} \mathrm{~S}\right)[1]\right)$. In the past years, several efforts such as long-term air monitoring to establish patterns or changes of environmental exposures, improve validity and representativeness of data, and prevent exposure misclassification [2] taking place. Campagna and co-workers findings are consistent with the hypothesis that exposure to malodorous sulfur compounds increases the risk of respiratory problems and symptoms. They suggest that ambient levels of $\mathrm{H}_{2} \mathrm{~S}$ may have been associated with exacerbations of asthma or other respiratory diseases among residents of Dakota City and South Sioux City during 1998-2000 [3].

Recently, Jeffrey explains that respiratory symptoms are the most frequently increased endpoint among both children and adults exposed to chronic low-level $(\sim<10 \mathrm{ppm}) \mathrm{H}_{2} \mathrm{~S}$ exposure from both anthropogenic and natu- 
ral sources. They conclude that such effect appears to be temporary, given that there is no consistent evidence of pulmonary function deficits in either age group among those chronically exposed to low $\mathrm{H}_{2} \mathrm{~S}$ concentrations. It is also indicated that "findings of respiratory symptoms may be the result of selective recall or an agitation effect from the pungent odor produced by $\mathrm{H}_{2} \mathrm{~S}$ ” [4].

Environmental Protection Agency established an inhalation reference concentration (RfC) by dividing the No-observed-adverse-effect level adjusted for dosimetric differences across species to a human equivalent concentration. (NOAEL) HEC for nasal effects by the Uncertainty factors (UF) of 300 yields an inhalation RfC of $0.002 \mathrm{mg} / \mathrm{m}^{3}$ [5]. Inhalation Reference Concentration (RfC) is based on the assumption that thresholds exist for certain toxic effects such as cellular necrosis. The inhalation RfC considers toxic effects for both the respiratory system (portal-of-entry) and for effects peripheral to the respiratory system (extra respiratory effects). The RfC is an estimate (with uncertainty spanning perhaps an order of magnitude) of a daily inhalation exposure of the human population (including sensitive subgroups) [5].

In this paper, we address the concerns of communities in the southeast of Mexico (see Figure 1), which have been exposed to low levels of $\mathrm{H}_{2} \mathrm{~S}$. We determined ambient concentrations of $\mathrm{H}_{2} \mathrm{~S}$ by modeling the $\mathrm{H}_{2} \mathrm{~S}$ emissions dispersion. Results were combined with a specific questionnaire to exposed population. Finally, a hazard quotient is obtained for different age groups. The purpose of the current health investigation is to determine whether general population has experienced a chronic exposure to $\mathrm{H}_{2} \mathrm{~S}$, demonstrate a possible pollution problem in this geographic area and to fill an important data gap regarding the health effects of $\mathrm{H}_{2} \mathrm{~S}$ in the ambient.

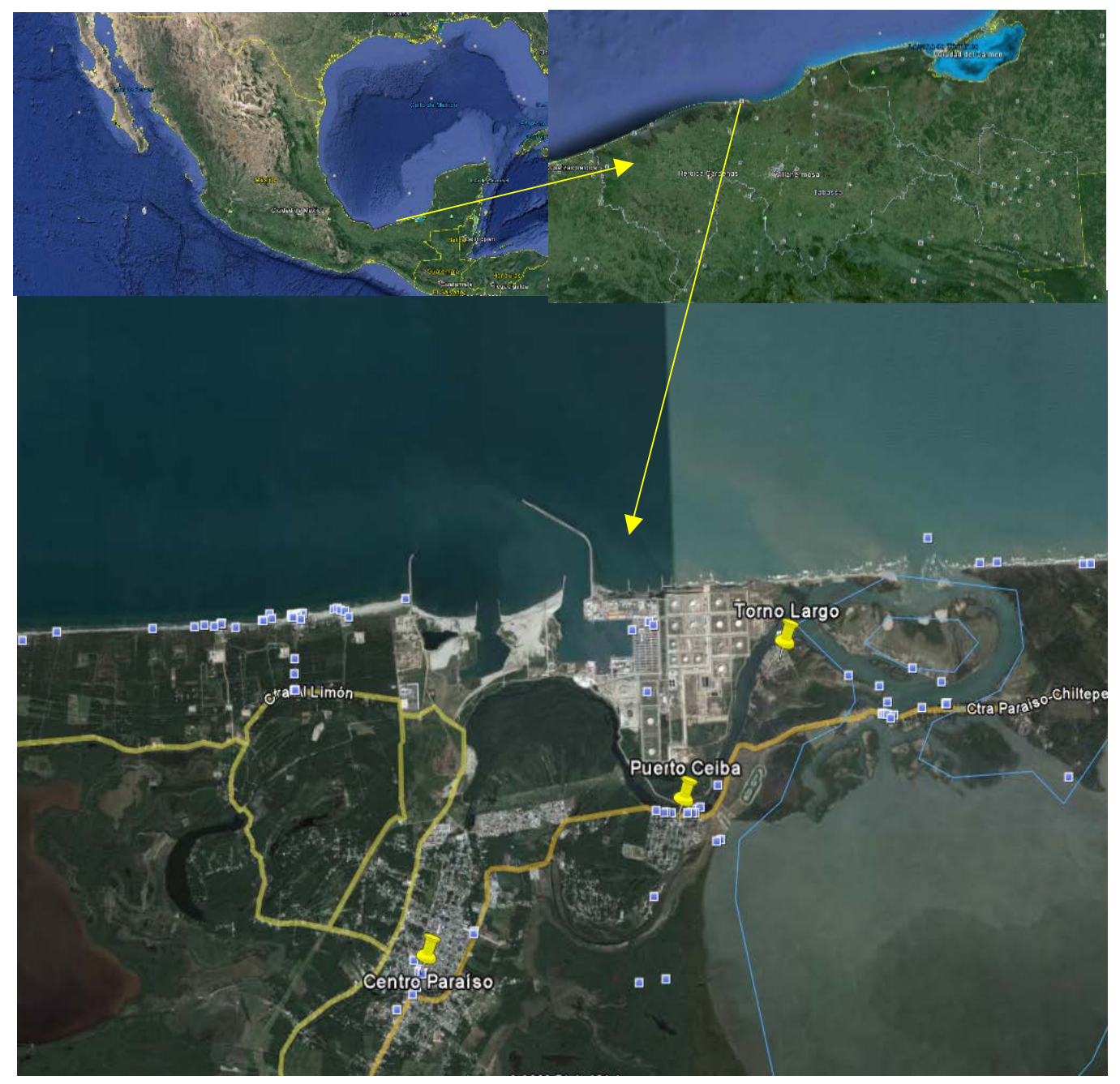

Figure 1. Geographic position of selected receptors. 


\section{Study Area}

Paraíso town is a municipality located in the north of the State of Tabasco in Mexico, about $75 \mathrm{~km}$ at north of the state capital. Main economic activities are fishing and agriculture, and currently, it is also an important oil producing area in the port of Dos Bocas.

The land is part of the Tabasco floodplain on the Gulf of Mexico with an average elevation of only two meters above sea level. The soil is sandy with some clay mixed nearest the ocean with clay dominating inland. This area has abundant surface water in the forms of lagoons, lakes, estuaries and wetlands. Major bodies of water include lakes and lagoons such as Mecoacán, La Machona, Tupilco, Puente de Ostión, La Encerrada (Amatillo), Tres Palmas, El Zorro, Arrastradero, Las Flores, Lagartera Tilapa, Manatí and El Eslabón.

Surface water flow in the municipality is split into east and west, both connected by the Río Seco River and the Jobo Canal. The east is dominated by the Mecoacán lagoon which opens into the Gulf of Mexico at Dos Bocas. Linked to it are smaller lagoons such as the Eslabón, La Tinaja and El Carmen.

The climate is hot and wet with rains during the summer/fall with an average annual rainfall of $1751.4 \mathrm{~mm}$. The coldest months are November, December and January with average temperatures around $22^{\circ} \mathrm{C}$. The hottest month is May with average temperatures around $30^{\circ} \mathrm{C}$. The windiest months are October, November and December when winds can reach $30 \mathrm{~km} / \mathrm{hr}$.

This area has perennial rainforest with trees between fifteen and thirty meters tall. However, most of these areas are disturbed. In the low ocean front areas there are beaches and mangroves. There is the occasional nopal cactus. Wildlife is mostly limited to bird and reptile species such as storks, kingfishers, seagulls, buzzards, marine and freshwater turtles, and various small lizards.

\section{Methods}

\section{1. $\mathrm{H}_{2} \mathrm{~S}$ Emissions}

A set of representative sampling points over all effluent treatment plant were designed for sampling the oil dehydration residual water, during the period of December 2008 to January 2009. Main considered components were: regulating sump, Archimedes water pump, API separator and regulating pond. Sampling consisted of $1 \mathrm{l}$ of residual water in each sampling point. $\mathrm{H}_{2} \mathrm{~S}$ emissions concentration were established analyzing oil dehydration residual water Experimental values were used to feed WATER 9 V3 model process [6]. The basic equation for models that predict emissions from water surfaces, employ the following equation

$$
E a=K A M C
$$

where

$E a=$ atmospheric emissions in $\mathrm{g} / \mathrm{s}$.

$K=$ Mass transfer coefficient in $\mathrm{m} / \mathrm{s}$.

$A=$ area in square meters.

$M=$ molecular weight of the liquid phase in $\mathrm{g} / \mathrm{mol}$.

$C=$ compound molar concentration in the liquid phase in $\mathrm{mol} / \mathrm{m}^{3}$.

WATER 9 model solves this equation for each part of the process to obtain final result (see Table 1).

\subsection{Modeling}

Meteorological information was produced using RAMS model with three nested grids that were spaced 40, 10 and $1 \mathrm{~km}$, respectively. External grid included Gulf of Mexico and part of Pacific Ocean, while internal one covers an area of $35 \times 30 \mathrm{~km}$ around Dos Bocas Maritime Terminal (DBMT) (see Figure 2).

Some of the parameters considered are:

- Constant rugosity over all domain, 0.05 meters.

- Albedo constant: 0.15 .

- Constant water surface temperature: $290^{\circ} \mathrm{K}$.

- Topography resolution less than $1 \mathrm{~km}$ (30 seconds).

- Climatological temperature equal to sea temperature.

One meteorological scenario representing average conditions was chosen, based on a meteorological analysis of 2005-2007 data. A second one, representing critical conditions was determined upon less favorable meteorological conditions for dispersion. 


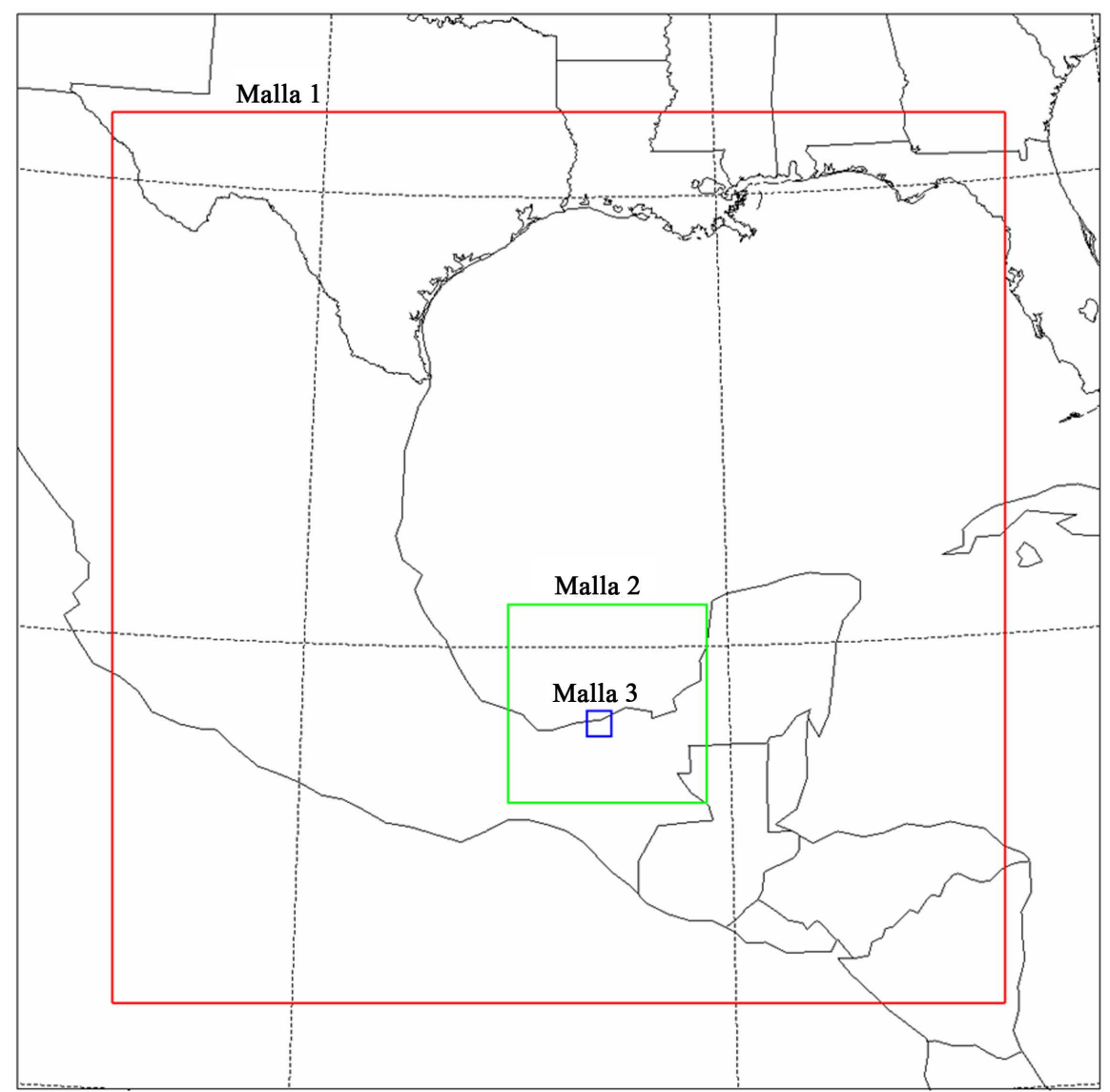

Figure 2. Nested grids for RAMS model.

Table 1. $\mathrm{H}_{2} \mathrm{~S}$ emissions.

\begin{tabular}{ccc}
\hline & g/s & ton/day \\
\hline Average & 4.50 & 0.39 \\
Maximum & 10.90 & 0.94 \\
Minimum & 0.85 & 0.07
\end{tabular}

After simulating the two meteorological scenarios, CALRAMS was used to extract required variables for CALPUFF model.

Dispersion modeling was performed with CALPUFF, considering maximum and average $\mathrm{H}_{2} \mathrm{~S}$ emissions. Three receptors were considered of particular significance, Paraíso and Puerto Ceiba (see Table 2).

Emissions dispersion modeling on meteorological scenario representing average conditions did not produce any considerable $\mathrm{H}_{2} \mathrm{~S}$ concentration on selected receptors. On the other hand, emissions dispersion modeling on scenario representing less favorable meteorological conditions did produce significant amounts of $\mathrm{H}_{2} \mathrm{~S}$ in selected receptors (Table 3), specifically in Paraíso and Puerto Ceiba.

\subsection{Exposure Assessment}

A probabilistic approach to estimate the potential for non-carcinogenic health effects it is not used. Instead, the potential for no carcinogenic effects is evaluated by comparing an exposure level over a specified time period (e.g., lifetime) with a reference dose derived for a similar exposure period [7]. This ratio of exposure to toxicity is called Noncancer Hazard Quotient (NHQ):

$$
\mathrm{NHQ}=E / R f D
$$

where: 
$E=$ exposure level (or intake);

$R f D=$ reference dose.

$E$ and $R f D$ are expressed in the same units and represent the same exposure period (i.e., chronic, sub chronic, or shorter-term).

Exposure was obtained applying a questionnaire to inhabitants of Paraiso, Puerto Ceiba and Torno Largo. Questionnaire activities took place from November 20, 2008 to February 2, 2009. It requested for amount of time (hr.), kind of outdoor specific activities for each family member and frequency. Another demanded information included:

- Place of living,

- Age (years),

- Weight (kg),

- Residence time (years),

- Working place,

- Spent time on outdoor activities.

\section{Results}

Outdoor spent time was obtained adding up the amount of time of every outdoor specific activities multiplied by the frequency and for 52, for each individual and each age group. Outdoor spent time results for 680 questioned people are shown in Table 4, and inhalation rate for the same group are in the Table 5. These results were combined with dispersion modeling to get Noncancer Hazard Quotient.

NHQ results are shown in Table 6 and Table 7. It is important to notice that Hazard is present only for Paraíso inhabitants and considering that $\mathrm{H}_{2} \mathrm{~S}$ air concentration is the maximum.

\section{Discussion and Conclusions}

It is important to mention that maximum $\mathrm{H}_{2} \mathrm{~S}$ concentration is present $26 \%$ of the time, so to be realistic we have to consider a weighted scenario. Table 8 describes corrected $\mathrm{NHQ}\left(\mathrm{NHQ}_{\mathrm{c}}\right)$ values. $\mathrm{NHQ}_{\mathrm{c}}$ highest values are found in Paraíso for over 19 years old group, 0.49. Additionally, it can be mentioned that NHQ might be overestimated due to a lack of inclusion of $\mathrm{H}_{2} \mathrm{~S}$ decaying rate in dispersion calculations. At this stage of knowledge, it can be concluded that there is no threat to human health due to the $\mathrm{H}_{2} \mathrm{~S}$ emission of DBMT, since all NHQ values are below 1 in all three most populated places surrounding maritime terminal.

Although this result is not worrying, attention should be paid to specific effects in age groups. Children and adults exposed to chronic low-level might have an increase in respiratory symptoms [4]. It is also worthy to emphasize that no measurement for $\mathrm{H}_{2} \mathrm{~S}$ is available, neither epidemiological studies to make a conclusive to properly assess health hazard among population surrounding DBMT. It should be remembered, as with many other substances, that $\mathrm{H}_{2} \mathrm{~S}$ reference dose is based mostly on toxicological studies in animals and on limited evidence regarding health effects in humans.

Table 2. Receptors and geographic position.

\begin{tabular}{ccccc}
\hline Receptor & Latitude & Longitude & UTM E (Km) & UTM N (Km) \\
\hline Paraíso & $18^{\circ} 23^{\prime} 44.06 " \mathrm{~N}$ & $93^{\circ} 12^{\prime} 52.21 " \mathrm{~W}$ & 477.343 & 2033.964 \\
Puerto Ceiba & $18^{\circ} 24^{\prime} 48.53 " \mathrm{~N}$ & $93^{\circ} 10^{\prime} 41.39^{\prime \prime} \mathrm{W}$ & 481.184 & 2035.942 \\
Torno Largo & $18^{\circ} 25^{\prime} 56.03^{\prime \prime} \mathrm{N}$ & $93^{\circ} 9^{\prime} 47.64 " \mathrm{~W}$ & 482.762 & 2038.015 \\
\hline
\end{tabular}

Table 3. Average 24 hrs. $\mathrm{H}_{2} \mathrm{~S}$ concentrations $\left(\mu \mathrm{g} / \mathrm{m}^{3}\right)$ for less favorable meteorological conditions.

\begin{tabular}{cccccc}
\hline & \multicolumn{3}{c}{ Average emission simulation } & \multicolumn{2}{c}{ Maximum emissions simulation } \\
\cline { 2 - 6 } Receptor & 02-Sep-06 & 03-Sep-06 & 04-Sep-06 & 02-Sep-06 & 03-Sep-06 \\
\hline Paraíso & 376 & 644 & 30 & 192 & 328 \\
Puerto Ceiba & 148 & 1 & 144 & 76 & 0 \\
Torno Largo & 1 & 0 & 0 & 0 & 0 \\
\hline
\end{tabular}


Table 4. Outdoor spent time.

\begin{tabular}{|c|c|c|c|c|}
\hline Age group & Age (years) & Weight (Kg) & Residence time (years) & Outdoor time (days/year) \\
\hline Adult (>19 years) & 37.65 & 69.24 & 29.20 & 68.90 \\
\hline Young (15 - 18 years) & 16.71 & 59.50 & 15.48 & 52.12 \\
\hline Young (12 - 14 years) & 13.26 & 47.13 & 12.64 & 60.00 \\
\hline Children (9 - 11 years) & 9.83 & 37.53 & 9.25 & 39.24 \\
\hline Children (6 - 8 years) & 6.98 & 26.83 & 6.63 & 43.39 \\
\hline Children (3 - 5 years) & 4.00 & 18.28 & 3.83 & 36.61 \\
\hline Infant (1 - 2 years) & 1.59 & 12.00 & 1.59 & 31.29 \\
\hline Infant $(<1$ year) & 0.40 & 6.29 & 0.40 & 22.60 \\
\hline
\end{tabular}

Table 5. Inhalation rate by age group.

\begin{tabular}{|c|c|c|c|}
\hline Age group & Daily inhalation rate indoors ( $\mathbf{m}^{3} /$ day) & Daily inhalation rate outdoors $\left(\mathrm{m}^{3} / \mathrm{day}\right)$ & Number of persons \\
\hline Adult ( $>19$ years) & $15.2^{+}$ & $15.2^{+}$ & 410 \\
\hline Young (15 - 18 years) & $17.0^{+}$ & $17.0^{+}$ & 56 \\
\hline Young (12 - 14 years) & $15.0^{+}$ & $15.0^{+}$ & 39 \\
\hline Childern (9 - 11 years) & 14.0 & 14.0 & 40 \\
\hline Childern (6 - 8 years) & 10.0 & 10.0 & 48 \\
\hline Childern (3 - 5 years) & 8.3 & 8.3 & 48 \\
\hline Infant (1 - 2 years) & 6.8 & 6.8 & 32 \\
\hline Infant (<1 year) & 4.5 & 4.5 & 7 \\
\hline Total & & & 680 \\
\hline
\end{tabular}

\section{Table 6. Paraiso’s NHQ results.}

\begin{tabular}{ccccc}
\hline NHQ & $\mathbf{E}\left(\boldsymbol{\mu g} / \mathbf{m}^{3}\right)$ & RfD $\left(\boldsymbol{\mu g} / \mathbf{m}^{3}\right)$ & Place & Group age \\
\hline 0.08 & 0.2 & 2.1 & Paraíso & 1 a 2 \\
0.26 & 0.6 & 2.1 & Paraíso & 3 a 5 \\
0.50 & 1.1 & 2.1 & Paraíso a 8 & 9 a 11 \\
0.71 & 1.5 & 2.1 & Paraíso & 12 a 14 \\
1.00 & 2.1 & 2.1 & Paraíso & 15 a 18 \\
1.15 & 2.5 & 2.1 & Paraíso & $>19$ \\
1.27 & 2.7 & 2.1 & Paraíso & Paraíso \\
\hline
\end{tabular}


Table 7. NHQ results for Puerto Ceiba and Torno Largo.

\begin{tabular}{|c|c|c|c|c|}
\hline NHQ & $E\left(\mu \mathrm{g} / \mathrm{m}^{3}\right)$ & $\mathbf{R f D}\left(\boldsymbol{\mu g} / \mathbf{m}^{3}\right)$ & Place & Group age \\
\hline 0.02 & 0.0 & 2.1 & Puerto Ceiba & $<1$ \\
\hline 0.07 & 0.2 & 2.1 & Puerto Ceiba & 1 a 2 \\
\hline 0.14 & 0.3 & 2.1 & Puerto Ceiba & 3 a 5 \\
\hline 0.20 & 0.4 & 2.1 & Puerto Ceiba & 6 a 8 \\
\hline 0.28 & 0.6 & 2.1 & Puerto Ceiba & 9 a11 \\
\hline 0.32 & 0.7 & 2.1 & Puerto Ceiba & 12 a 14 \\
\hline 0.36 & 0.8 & 2.1 & Puerto Ceiba & 15 a 18 \\
\hline 0.52 & 1.1 & 2.1 & Puerto Ceiba & $>19$ \\
\hline 0.00 & 0.0 & 2.1 & Torno Largo & $<1$ \\
\hline 0.00 & 0.0 & 2.1 & Torno Largo & 1 a 2 \\
\hline 0.00 & 0.0 & 2.1 & Torno Largo & 3 a 5 \\
\hline 0.01 & 0.0 & 2.1 & Torno Largo & 6 a 8 \\
\hline 0.01 & 0.0 & 2.1 & Torno Largo & 9 a11 \\
\hline 0.01 & 0.0 & 2.1 & Torno Largo & 12 a 14 \\
\hline 0.01 & 0.0 & 2.1 & Torno Largo & 15 a 18 \\
\hline 0.01 & 0.0 & 2.1 & Torno Largo & $>19$ \\
\hline
\end{tabular}

Table 8. Corrected NHQ results.

\begin{tabular}{ccc}
\hline NHQ $_{\mathbf{c}}$ & Place & Group age \\
\hline 0.02 & Paraíso & $<1$ \\
0.07 & Paraíso & 1 a 2 \\
0.13 & Paraíso & 3 a 5 \\
0.19 & Paraíso & 6 a 8 \\
0.27 & Paraíso & 9 a11 \\
0.31 & Paraíso & 12 a 14 \\
0.34 & Paraíso & 15 a 18 \\
0.49 & Paraíso & $>19$ \\
\hline
\end{tabular}

It would be suitable to establish an appropriate risk level based on a reliable body of evidence from epidemiological studies of population exposed to lower levels of $\mathrm{H}_{2} \mathrm{~S}$.

\section{References}

[1] White, M.C., Inserra, S.G., Berger, S.A., Campagna, D., Phifer, B.L. and Lybarber, J.A. (1999) Health Concerns for Communities Exposed to Hydrogen Sulfide. A Perspective from Two Communities. Environmental Epidemiology and Toxicology, 1, 236-240.

[2] Inserra, S., Phifer, B., Pierson, R. and Campagna, D. (2002) Community-Based Exposure Estimates for Hydrogen Sulfide. Journal of Exposure Science and Environmental Epidemiology, 12, 124-129. http://dx.doi.org/10.1038/sj.jea.7500207

[3] Campagna, D., Kathman, S.J., Pierson, R., Inserra, S.G., Phifer, B.L., Middleton, D.C., Zarus, G.M. and White, M.C. 
(2004) Ambient Hydrogen Sulfide, Total Reduced Sulfur, and Hospital Visits for Respiratory Diseases in Northeast Nebraska, 1998-2000. Journal of Exposure Science and Environmental Epidemiology, 14, 180-187.

http://dx.doi.org/10.1038/sj.jea.7500313

[4] Lewis, J. (2014) Chronic Low-Level Hydrogen Sulfide Exposure and Potential Effects on Human Health: A Review of the Epidemiological Evidence. Critical Reviews in Toxicology, 45, 1-31.

[5] EPA (2003) US Environmental Protection Agency. Hydrogen Sulfide (CASRN 7783-06-4). http://www.epa.gov/IRIS/subst/0061.htm

[6] EPA (2001) US Environmental Protection Agency. USER'S GUIDE FOR WATER9 SOFTWARE Version 2.0.0., US Environmental Protection Agency, Office of Air Quality Planning and Standards, Research Triangle Park.

[7] EPA (1989) US Environmental Protection Agency. Risk Assessment Guidance for Superfund Volume 1 Human Health Evaluation, Manual (Part A) Interim Final. EPA/540/1-89/002, Environmental Protection Agency, Office of Emergency and Remedial Response, Washington DC. 